\title{
Flavonoids, NodD1, NodD2, and Nod-Box NB15 Modulate Expression of the y4wEFG Locus That Is Required for Indole-3-Acetic Acid Synthesis in Rhizobium sp. strain NGR234
}

\author{
Mart Theunis, ${ }^{1}$ Hajime Kobayashi, ${ }^{2}$ William J. Broughton, ${ }^{2}$ and Els Prinsen ${ }^{1}$ \\ ${ }^{1}$ Laboratory of Plant Physiology and Biochemistry, Department of Biology, University of Antwerp, Universiteitsplein 1, B- \\ 2610 Antwerp, Belgium; ${ }^{2}$ Laboratoire de Biologie Moléculaire des Plantes Supérieures (LBMPS), Université de Genève, \\ Sciences III, 30 quai Ernest-Ansermet 211 Genève 4, Switzerland
}

Submitted 20 November 2003. Accepted 15 June 2004.

Flavonoids secreted by host plants activate, in conjunction with the transcriptional activator NodD, nod gene expression of rhizobia resulting in the synthesis of Nod factors, which trigger nodule organogenesis. Interestingly, addition of inducing flavonoids also stimulates the production of the phytohormone indole-3-acetic acid (IAA) in several rhizobia. Here, the molecular basis of IAA synthesis in Rhizobium sp. NGR234 was investigated. Mass spectrometric analysis of culture supernatants indicated that NGR234 is capable of synthesizing IAA via three different pathways. The production of IAA is increased strongly by exposure of NGR234 to daidzein in a NodD1-, NodD2-, and SyrM2-dependent manner. This suggests that the $\mathrm{y} 4 \mathrm{wEFG}$ locus that is downstream of nod-box NB15 encodes proteins involved in IAA synthesis. Knockout mutations in $\mathrm{y} 4 \mathrm{wE}$ and $\mathrm{y} 4 \mathrm{wF}$ abolished flavonoid-inducible IAA synthesis and a functional y4wF was required for constitutive IAA production. The promoter activity of NB15 and IAA production both were enhanced by introduction of a multicopy plasmid carrying nodD2 into NGR234. Surprisingly, the y4wE mutant still nodulated Vigna unguiculata and Tephrosia vogelii, although the nodules contained less IAA and IAA conjugates than those formed by the wild-type bacterium.

Additional keywords: auxin, nodulation, tryptophan.

Legume root-nodule bacteria (genera Azorhizobium, Bradyrhizobium, Mesorhizobium, and Rhizobium, collectively called rhizobia) provoke nitrogen-fixing symbioses in conjunction with an appropriate legume partner. Symbiosis is initiated when flavonoids, which accumulate in the rhizosphere of the host-plant, trigger expression of nodulation (nod) genes by interacting with NodD, one of a family of LysR-type transcriptional activators. Tetrameric NodD proteins bind to $c i s$-regulatory elements (nod-boxes) that are found in the promoter regions of most nod genes, and activate transcription in the presence of compatible flavonoids (Feng et al. 2003; Fischer and Long 1993). Most of these nodulation genes (nod, noe, and nol) are involved in the syn-

Corresponding author: E. Prinsen; E-mail: els.prinsen@ ua.ac.be M. Theunis and H. Kobayashi contributed equally to this work. thesis of host-specific lipo-chito-oligosaccharides (LCOs) called Nod factors that are essential for the initial infection of root hairs (Downie 1998; Perret et al. 2000).

Some plant-associated bacteria, including rhizobia, have the capacity to produce the plant hormone indole-3-acetic acid (IAA) (Badenoch-Jones et al. 1982; Basu and Ghosh 1998, 2001; Datta and Basu 1998, 2000; Ernstsen et al. 1987; Fukuhara et al. 1994; Kawaguchi et al. 1990; Minamisawa and Fukai 1991; Patten and Glick 1996). So far, three bacterial IAA biosynthesis pathways have been characterized: tryptophan can be converted to IAA via indole-3-acetamide, tryptamine, or indole-3-pyruvic acid (Fig. 1) (Costacurta and Vanderleyden 1995; Patten and Glick 1996). Phytohormone production is known to be involved in pathogenesis (Jameson 2000; Morris 1995), but the role of bacterial IAA in symbiosis remains unclear.

Interestingly, in Rhizobium meliloti and R. leguminosarum, the production of IAA is enhanced in the presence of nod-inducing flavonoids (Prinsen et al. 1991), suggesting that rhizobial genes involved in IAA production are regulated in a host-specific manner. Rhizobium sp. NGR234, which nodulates over 112 genera of legumes (Pueppke and Broughton 1999), has a symbiotic plasmid (pNGR234a) that encodes two nodD homologues (nodD1 and nodD2) as well as 19 nod-boxes (NB1 through NB19) (Freiberg et al. 1997; Kobayashi et al. 2004; Perret et al. 1999). Daidzein can induce transcription of all nod-box-lac $Z$ fusions, with the exception of NB3. The protein encoded by nodD1 is the key activator of flavonoid-inducible loci (Kobayashi et al. 2004). NodD2 is involved in the delayed repression of several Nodfactor synthetic genes and is specifically required for optimal transcription of some nod-boxes (Fellay et al. 1998; Kobayashi et al. 2004). In turn, expression of nodD2 requires proteins encoded by syrM2 (another member of the LysR family), which is controlled by NB19. Thus, NodD1, SyrM2, and NodD2 form a regulatory cascade that coordinates the expression of at least 42 genes in a flavonoid- and host-specific manner. Here, we show that IAA production by NGR234 is stimulated by flavonoids, and that the y4wEFG locus, which is immediately downstream of $\mathrm{NB} 15$, is required for IAA synthesis. Although IAA levels in nodules infected with an y4wE-defective mutant were reduced significantly, the flavonoid-inducible IAA synthesis of NGR234 is not essential for establishment of symbiosis with the two host plants tested. 


\section{RESULTS}

IAA synthesis pathways in NGR234.

In the absence of tryptophan, several storage and breakdown products of the indole-3-pyruvic acid (IPyA) pathway (Fig. 1, number 3), including indole-3-lactic acid (ILA), indole-3-aldehyde (IAld), and indole-3-ethanol (IEt), were detected in the supernatants of NGR234 (Fig. 2, open bars). Upon addition of exogenous tryptophan to the cultures, NGR234 secreted substantial amounts of the intermediates indole-3-acetaldehyde (IAAld), IPyA, indole-3-acetamide (IAM), and tryptamine (Tra) (Fig. 2, black bars). Thus, NGR234 is capable of synthesizing IAA via the three pathways previously identified in other bacteria. Nevertheless, the IPyA pathway (Fig. 1, number 3 ) is predominant when the supply of tryptophan is limited.

\section{Flavonoids enhance IAA synthesis in a NodD-dependent manner.}

In the presence of $0.2 \mu \mathrm{M}$ daidzein, IAA levels in NGR234 supernatants were increased significantly compared with those found under noninduced conditions (Fig. 3). Luteolin, another flavonoid, also enhanced IAA production by NGR234 (data not shown). To determine the role of symbiotic transcription factors in flavonoid-induced IAA synthesis, IAA production

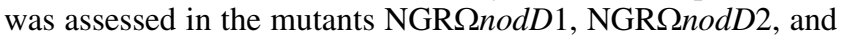

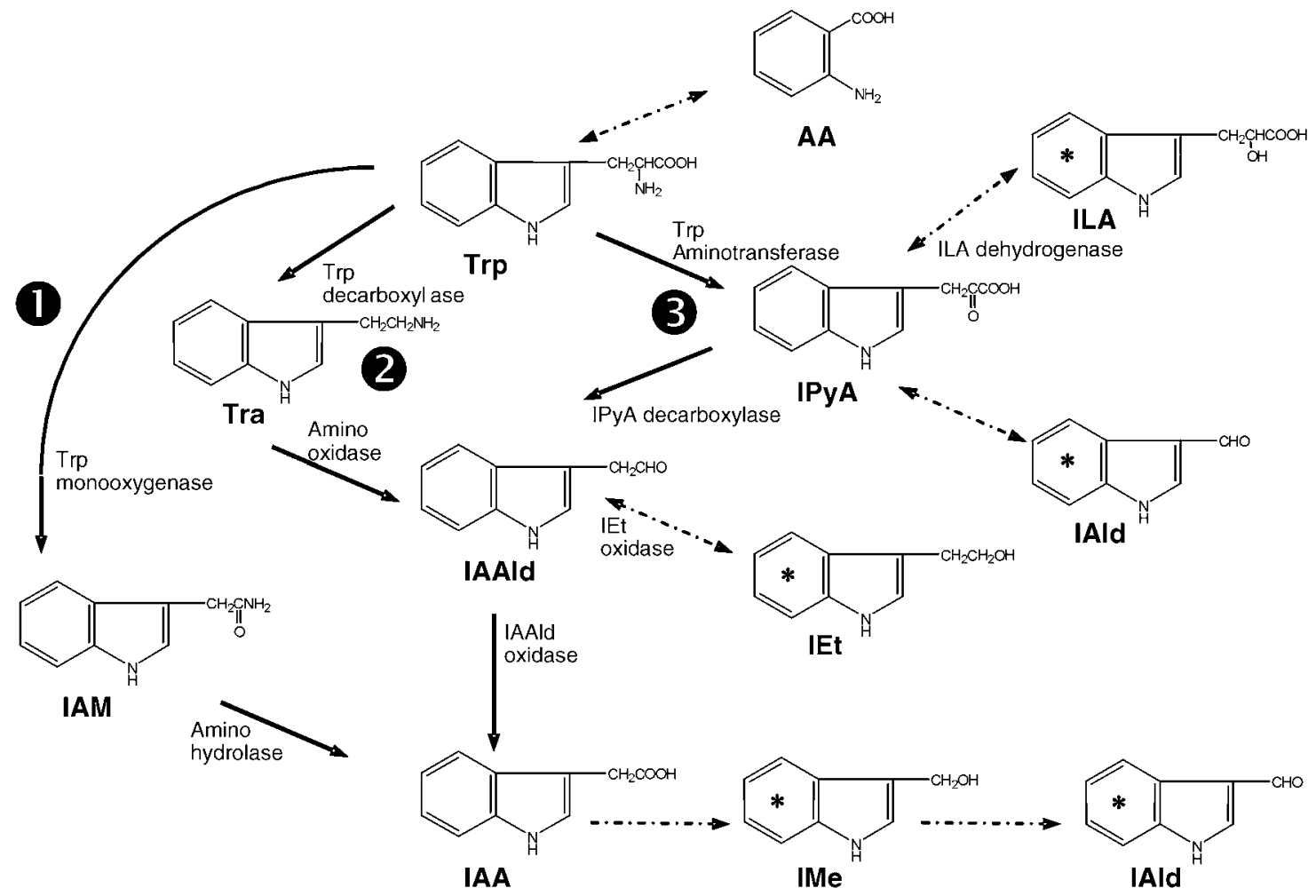

Fig. 1. Pathways of indole-3-acetic acid (IAA) synthesis starting from the precursor tryptophan. So far, three IAA biosynthetic pathways have been identified in rhizobia, via indole-3-acetamide (IAM; no. 1), tryptamine (Tra; no. 2), and indole-3-pyruvic acid (IPyA; no. 3). AA, antranilate; Trp, tryptophan; IPyA, indole-3-pyruvic acid; Tra, tryptamine; IAAld, indole-3-acetaldehyde; IAM, indole-3-acetamide; ILA, indole-3-lactic acid; IAld, indole-3aldehyde; IEt, indole-3-ethanol; IMe, indole-3-methanol. Breakdown and storage products are labeled by *.

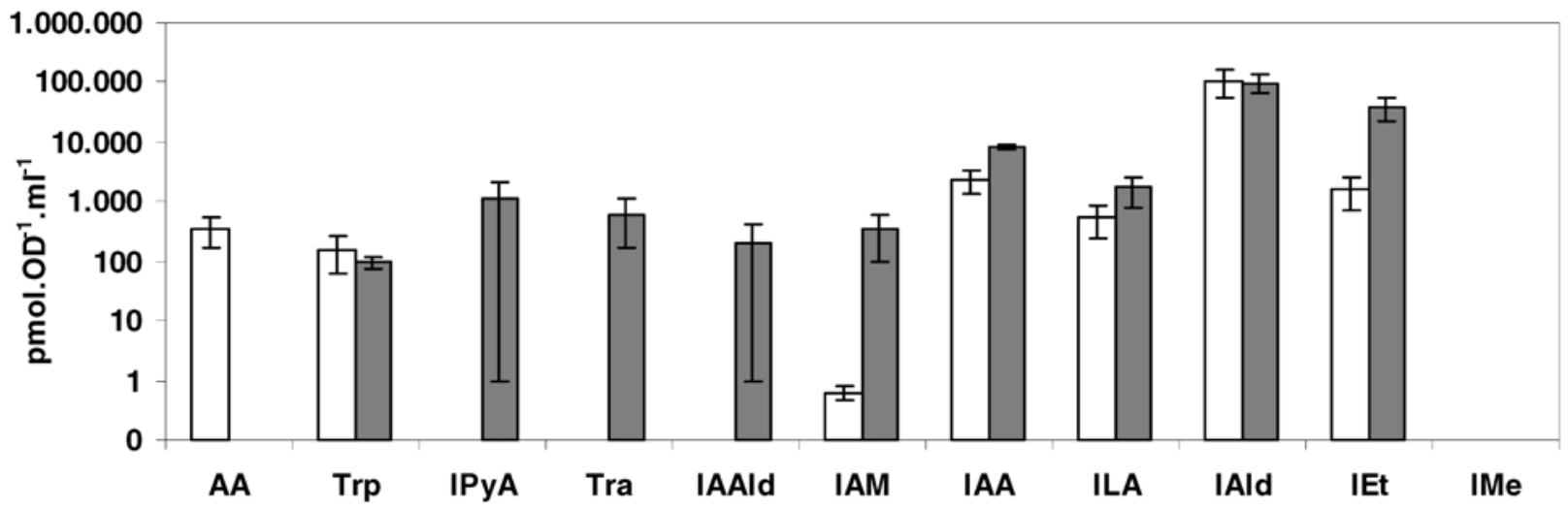

Fig. 2. Intermediates of indole-3-acetic acid (IAA) synthesis found in the supernatants of Rhizobium sp. NGR234 grown in Rhizobium minimal medium containing succinate as the carbon source (RMS) (open bars) or RMS supplemented with tryptophan ( $5 \mu \mathrm{g} \mathrm{ml}^{-1}$, gray bars). Samples were taken $36 \mathrm{~h}$ after the addition of tryptophan and analyzed by liquid chromatography electro-spray interface-tandem mass spectrometry. Results are presented on a logarithmic scale. AA, antranilate; Trp, tryptophan; IPyA, indole-3-pyruvic acid; Tra, tryptamine; IAAld, indole-3-acetaldehyde; IAM, indole-3-acetamide; IAA, indole3-acetic acid; ILA, indole-3-lactic acid; IAld, indole-3-aldehyde; IEt, indole-3-ethanol; IMe, indole-3-methanol. 
NGRsyrM2::uidA. In the absence of daidzein, only basal, constitutive levels of IAA synthesis, similar to those found using the wild-type strain, were detected in the supernatants of the mutants (Fig. 3, open bars). Furthermore, addition of daidzein did not change the levels of IAA in the supernatants (Fig. 3, black bars), suggesting that flavonoid-inducible IAA synthesis is under control of the NodD1-SyrM2-NodD2 regulatory cascade.

\section{y4wEFG is involved in IAA synthesis.}

Flavonoid induction of IAA synthesis requires a functional nodD2; therefore, we speculated that one or more genes responsible for IAA synthesis are regulated by a NodD2 dependent nod-box. Of the 19 nod-boxes, four (NB6, NB15, NB16, and NB17) require NodD2 for their optimal activity (Kobayashi et al. 2004). Among them, NB15 is located upstream of three open reading frames (ORF): $\mathrm{y} 4 \mathrm{wE}, \mathrm{y} 4 \mathrm{wF}$, and $\mathrm{y} 4 \mathrm{wG}$ (Kobayashi et al. 2004) (Fig. 4). y4wE and y4wF code for a class-2 aminotransferase that is similar to the putative histidinol aminotransferase HisC and a monooxygenase, respectively (similarities ranged from 82 to $85 \%$ for $\mathrm{HisC}$ and 76 to $80 \%$ for monooxygenases). Although none of these homologues have been shown to be involved in IAA synthesis, similar enzymes, including an aminotransferase as well as an indole acetaldehyde oxidase, are involved in the IPyA pathway (Fig. 1, number 3). Most probably, y4wG is a cryptic ORF, because it possesses neither conserved domains nor homologues. To examine the involvement of $y 4 w E F G$ in IAA production, $\mathrm{y} 4 \mathrm{wE}$ and $\mathrm{y} 4 \mathrm{wF}$ were mutated ("knocked-out") by inserting an $\Omega$ interposon in their internal XhoI and $B g l \mathrm{II}$ sites, respectively (Table 1 ; Fig. 4). The resulting mutant NGR $\Omega w E$ showed a reduced level of constitutive IAA production (160 pmol optical density [OD] $]^{-1} \mathrm{ml}^{-1}$ ), which is less than $30 \%$ of the level produced by the wild type $\left(550 \mathrm{pmol} \mathrm{OD}^{-1} \mathrm{ml}^{-1}\right)$, and was not inducible by flavonoids $\left(220 \mathrm{pmol} \mathrm{OD}^{-1} \mathrm{ml}^{-1}\right)$ (Fig. 5). Surprisingly, the mutant NGR $\Omega w F$ was unable to produce IAA in both a constitutive and flavonoid-inducible manner ( 0 to 6 and 0 to $10 \mathrm{pmol} \mathrm{OD}^{-1} \mathrm{ml}^{-1}$, respectively) (Fig. 5). Introduction of the plasmid pwEFG, which carries NB15 and y4wEFG in a 5.8-kb BamHI fragment (Fig. 4) into both mutants, rescued constitutive and flavonoid-inducible IAA synthesis (Fig. 5), confirming that $\mathrm{y} 4 \mathrm{wE}$ and $\mathrm{y} 4 \mathrm{wF}$ are necessary for auxin synthesis in NGR234.

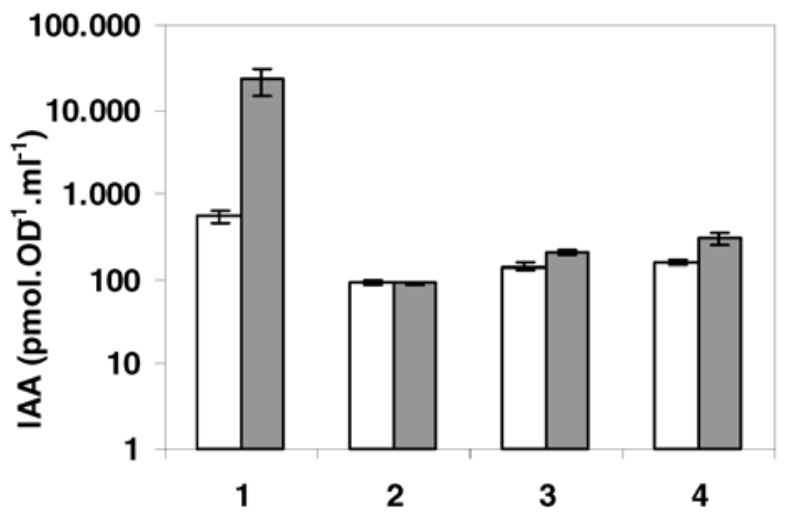

Fig. 3. Indole-3-acetic acid (IAA) concentrations present in the growth media of 1, Rhizobium sp. NGR234 and its mutants 2, NGR $\Omega$ nodD1; 3, NGRSnodD2; and 4, NGRsyrM2::uidA grown in Rhizobium minimal medium containing succinate as the carbon source in the absence (open bars) or presence (black bars) of the flavonoid daidzein $(0.2 \mu \mathrm{M})$. Samples were taken $36 \mathrm{~h}$ after the addition of daidzein and analyzed by gas chromatography-mass spectrometry. Results are presented on a logarithmic scale.
y4wE and y4wF encode for enzymes of the IPyA pathway.

The effect of daidzein on intermediates of IAA synthesis were also analyzed in supernatants of NGR234 (Fig. 6, open bars), NGR $\Omega w E$ (gray bars), and $N G R \Omega w F$ (black bars). Comparison of concentration of intermediates in the absence (Fig. 6A) or in the presence (Fig. 6B) of daidzein shows that daidzein induces the accumulation of IAld, IAAld, ILA, and IEt in wild-type NGR234, indicating that the IPyA pathway is responsible for the flavonoid-inducible IAA synthesis. Levels of these intermediates in both $\mathrm{NGR} \Omega \mathrm{wE}$ and $\mathrm{NGR} \Omega \mathrm{wF}$ were reduced significantly and were not increased in the presence of daidzein, indicating that $\mathrm{y} 4 \mathrm{wE}$ and $\mathrm{y} 4 \mathrm{wF}$ encode enzymes involved in the IPyA pathway.

\section{Regulation of the $y 4 w E F G$ cluster.}

To confirm the role of NodD2 in the regulation of IAA production, pRAF130 which contains multiple copies of nodD2 (Fellay et al. 1998) was mobilized into NGR234, NGR(pMP-NB8), NGR(pMP-NB15), and NGR234(pMPnodD1p) (Kobayashi et al. 2004). Introduction of nodD2 on a multiple copy-number plasmid totally abolished the basal activity of nodD1 and the induction of the activity of NB8 (the nod-box which regulates synthesis of the Nod-factor core) (Table 2), confirming the suppressor role of NodD2 (Fellay et al. 1998). In contrast, NB15 showed strong constitutive promoter activity even in the absence of daidzein, which was manifested by high levels of constitutive IAA production (25 nmol $\mathrm{OD}^{-1} \mathrm{ml}^{-1}$ ) in the NGR234(pRAF130) transconjugant (Fig. 5), suggesting that NodD2 can activate transcription from NB15 in the absence of an inducer.

To examine whether NB15 regulates transcription of both $\mathrm{y} 4 \mathrm{wE}$ and $\mathrm{y} 4 \mathrm{wF}$, we constructed $\mathrm{pwE}(\mathrm{F} \Omega) \mathrm{G}$ by inserting an $\Omega$ interposon into the $B g l \mathrm{II}$ site of $\mathrm{y} 4 \mathrm{wF}$ of pwEFG (Fig. 4). Assuming that the $\Omega$ interposon in $\mathrm{y} 4 \mathrm{wE}$ has polar effects on the downstream ORF $y 4 w F$ (i.e., that both $y 4 w E$ and $y 4 w F$ are co-transcribed from NB15 following flavonoid induction), mobilization of pwE(F $\Omega) \mathrm{G}$ into $\mathrm{NGR} \Omega w \mathrm{wE}$ did not restore flavonoid-inducible IAA synthesis even if the transconjugant also carried a functional y4wE. Only basal levels of IAA (500 pmol $\mathrm{OD}^{-1} \mathrm{ml}^{-1}$ ) were found in daidzein-treated cultures of NGR $\Omega w E(p w E(F \Omega) G)$ (Fig. 5); therefore, it is likely that transcription of both $\mathrm{y} 4 \mathrm{wE}$ and $\mathrm{y} 4 \mathrm{wF}$ is enhanced by NB15 in the presence of flavonoids.

Because residual amounts of IAA were found in the supernatants of the NGR $\Omega w E$ but not the NGR $\Omega w F$ mutants (Fig. 5 ), we studied the intergenic region between the two ORF for the presence of possible supplementary promoters. The ATG of $y 4 w F$ is $0.4 \mathrm{~kb}$ downstream of the $\mathrm{y} 4 \mathrm{wE}$ termination codon. For this reason, a $0.9-\mathrm{kb} X b a \mathrm{I}-N s i \mathrm{I}$ fragment containing the

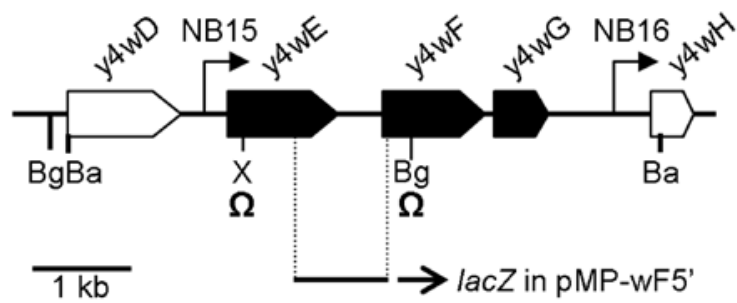

Fig. 4. Physical map of the y4wEFG locus of pNGR234a. A total of 407 bp separate $w E$ and $w F$, whereas there are 38 bp between $w F$ and $w G$ Restriction sites are as follows: Bam HI $(\mathrm{Ba}), B g l \mathrm{II}(\mathrm{Bg})$, and XhoI (X). y4wE was mutated by inserting a spectinomycin-resistant $\Omega$ cassette into the internal XhoI site. $\mathrm{y} 4 \mathrm{wF}$ was mutated by inserting a kanamycinresistant $\Omega$ cassette into the internal $B g l$ II site. Locations of the $\Omega$ insertions are shown by $\Omega$. The 952-bp fragment containing the intergenic region between $\mathrm{y} 4 \mathrm{wE}$ and $\mathrm{y} 4 \mathrm{wF}$ was fused to a promoterless lac $\mathrm{Z}$ gene for analysis of its promoter activity. 
complete intergenic region was cloned by polymerase chain reaction (PCR) and fused to a promoterless lacZ gene giving pMP-wF5' (Fig. 4; Table 1). When mobilized into NGR234 and its derivatives, weak constitutive activity that was independent of inducers and symbiotic regulators (75 \pm 4 Miller's units) was found, suggesting that a second promoter of $\mathrm{y} 4 \mathrm{wF}$ lies in the intergenic region.

\section{y4wEFG-dependent IAA synthesis in planta.}

To test the role of the flavonoid-inducible IAA synthesis in nodulation, Vigna unguiculata and Tephrosia vogelii were inoculated with NGR234 or NGR $\Omega w E$. NGR234 forms determinate and indeterminate nodules, respectively, on these hosts.
Although no significant differences were found in nodule number, plant growth, or intracellular structures of the nodules induced by the wild-type strain or the mutant on both plants (data not shown), the concentrations of both IAA and IAA conjugates were reduced significantly in nodules formed by NGR $2 w E$ (Fig. 7). This suggests that y4wEFG is also involved in IAA synthesis within nodules. However, nodules produced by NGR $\Omega w E$ transconjugants carrying pwEFG contained only mutant levels of IAA (Fig. 7). Possibly this was due to the instability of $\mathrm{NGR} \Omega w E(\mathrm{pwEFG})$ transconjugants within nodules, although random isolations of bacteria from nodules induced by $\mathrm{NGR} \Omega \mathrm{wE}(\mathrm{pwEFG})$ showed them all to be tetracycline resistant, implying that pwEFG had been main-

Table 1. Strains and plasmids used in this study

\begin{tabular}{|c|c|c|}
\hline & Relevant characteristics ${ }^{a}$ & Reference \\
\hline \multicolumn{3}{|l|}{ Strains } \\
\hline NGR234 & Rif $^{\mathrm{T}}$ derivative of wild-type NGR234 & Lewin et al. 1990 \\
\hline NGR $\Omega$ nodD1 & NGR234 derivative containing an $\Omega$ insertion in the BamHI site of nodD1, $\mathrm{Sp}^{\mathrm{r}}$ & Relić et al. 1993 \\
\hline NGR $\Omega$ nodD2 & NGR234 derivative containing an $\Omega$ insertion in the BamHI site of nodD2, $\mathrm{Km}^{\mathrm{r}}$ & Fellay et al. 1995 \\
\hline NGRsyrM2::uidA & NGR234 derivatives containing the $u i d A$ - $a p h$ insertion in the $S a c \mathrm{I}$ site of $s y r M 2, \mathrm{Km}^{\mathrm{r}}$ & Kobayashi et al. 2004 \\
\hline $\mathrm{NGR} \Omega \mathrm{wE}$ & NGR234 derivative containing an $\Omega$ insertion in the $X h o I$ site of $y 4 w E, \mathrm{Sp}^{\mathrm{r}}$ & This work \\
\hline $\mathrm{NGR} \Omega w F$ & NGR234 derivative containing an $\Omega$ insertion in the $B g I I I$ site of $y 4 \mathrm{wF}, \mathrm{Km}^{\mathrm{r}}$ & This work \\
\hline NGR(pwEFG) & NGR234 containing pwEFG & This work \\
\hline NGR $\Omega$ wE(pwEFG) & NGR $\Omega$ wE containing pwEFG & This work \\
\hline $\mathrm{NGR} \Omega w F(\mathrm{pwEFG})$ & NGR $\Omega w F$ containing pwEFG & This work \\
\hline $\mathrm{NGR}(\mathrm{pwE}(\mathrm{F} \Omega) \mathrm{G})$ & NGR234 containing pwE(Fת)G & This work \\
\hline $\mathrm{NGR} \Omega w E(p w E(F \Omega) G)$ & $\mathrm{NGR} \Omega w E$ containing $\mathrm{pwE}(\mathrm{F} \Omega) \mathrm{G}$ & This work \\
\hline \multicolumn{3}{|l|}{ Plasmids } \\
\hline pBluescriptII KS+ & Phage f1, lac Z, Ap ${ }^{\mathrm{r}}$ & Stratagene \\
\hline pBBR-MCS5 & Broad host range cloning vector, $\mathrm{Gm}^{\mathrm{r}}$ & Kovach et al. 1995 \\
\hline pLAFR-6 & $\begin{array}{l}\text { Broad host range vector containing transcriptional terminators flanking the cloning } \\
\text { site, } \mathrm{Tc}^{\mathrm{r}}\end{array}$ & $\begin{array}{l}\text { D. Dahlbech and } \\
\text { B. Staskawicz, unpublished }\end{array}$ \\
\hline pMP220 & IncP expression vector containing a promoterless lac $\mathrm{Z}$ gene, $\mathrm{Tc}^{\mathrm{r}}$ & Spaink et al. 1987 \\
\hline pwEFG & NB15 and y $4 \mathrm{wEFG}$ cloned into pLAFR- 6 as a $5.8-\mathrm{kb}$ BamHI fragment & This work \\
\hline $\mathrm{pwE}(\mathrm{F} \Omega) \mathrm{G}$ & pwEFG derivative containing an $\Omega$ insertion in the $B g I I I$ site of $y 4 w F$ & This work \\
\hline pMP-NB8 & NB8 cloned into pMP220 as a $0.3-\mathrm{kb} K p n \mathrm{I}-\mathrm{X} b a \mathrm{I}$ fragment & Kobayashi et al. 2004 \\
\hline pMP-NB15 & NB15 cloned into pMP220 as a 0.7-kb SpeI-PstI fragment & Kobayashi et al. 2004 \\
\hline pMP-nodD1p & Promoter of nodD 1 cloned into pMP220 as a $0.7-\mathrm{kb}$ Pst I fragment & Kobayashi et al. 2004 \\
\hline pRAF130 & A $2.1-\mathrm{kb}$ PstI-BglII fragment containing nodD2 cloned into pBBR1MCS-5 & Fellay et al. 1998 \\
\hline pMP-wF5' & The upstream region of $\mathrm{y} 4 \mathrm{wF}$ cloned into $\mathrm{pMP} 220$ as a $0.9-\mathrm{kb} \mathrm{XbaI}-N$ siI fragment & This work \\
\hline
\end{tabular}

${ }^{\mathrm{a}}$ Resistant to rifampicin $\left(\operatorname{Rif}^{\mathrm{r}}\right)$, spectinomycin $\left(\mathrm{Sp}^{\mathrm{r}}\right)$, kanamycin $\left(\mathrm{Km}^{\mathrm{r}}\right)$, ampicillin $\left(\mathrm{Ap}^{\mathrm{r}}\right)$, gentamycin $\left(\mathrm{Gm}^{\mathrm{r}}\right)$, and tetracycline $\left(\mathrm{Tc}^{\mathrm{r}}\right)$.

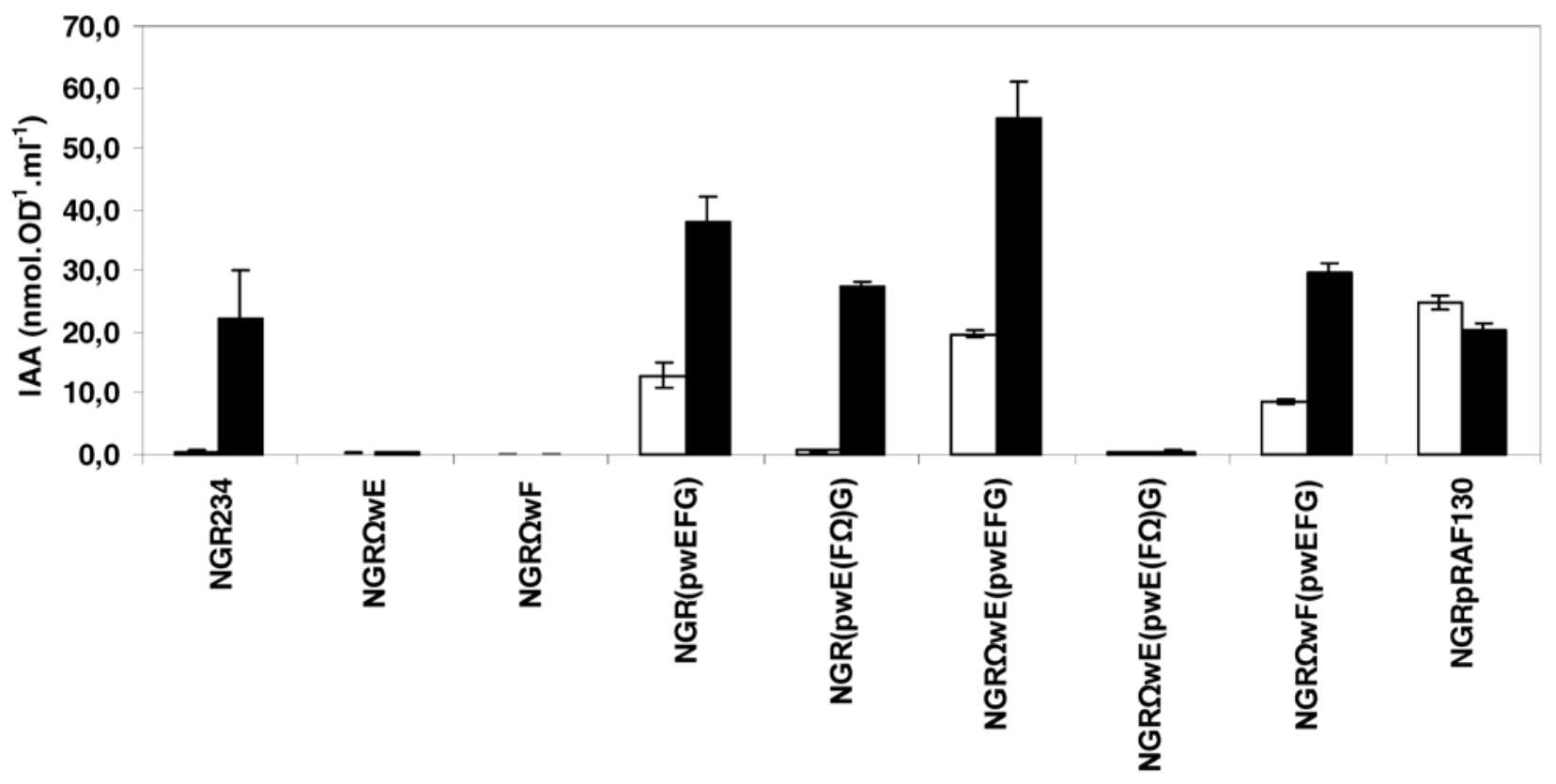

Fig. 5. Indole-3-acetic acid (IAA) concentrations in the supernatants of NGR234 and its derivatives grown in Rhizobium minimal medium containing succinate as the carbon source medium in the presence (black bars) or absence (open bars) of daidzein $(0.2 \mu \mathrm{M})$. Samples were taken $36 \mathrm{~h}$ after the addition of daidzein and analyzed by gas chromatography-mass spectrometry. 
tained in the bacteroids. A more likely explanation is that a different promoter, possibly the nifA $-\sigma^{54}$ promoter that is immediately upstream of y4wA (and approximately $6 \mathrm{~kb}$ from $\mathrm{y} 4 \mathrm{wE}$ ) (Freiberg et al. 1997), and which is active within nodules (Perret et al. 1999), is necessary for IAA synthesis within the plant. This nifA $-\sigma^{54}$ promoter is not present on the $5.8-\mathrm{kb}$ Bam $\mathrm{H} 1$ fragment carried on pwEFG.

\section{DISCUSSION}

Interestingly, many plant-associated bacteria, including rhizobia, have the capacity to produce the essential plant hormone IAA. As far as is known, IAA biosynthesis in symbiotic bacteria occurs via the IAM, IPyA, and, to a lesser extent, Tra pathways (Fig. 1) (Costacurta and Vanderleyden 1995; Patten and Glick 1996). Biochemical activity of the IAM pathway (Fig. 1, number 1) has been demonstrated in Bradyrhizobium japonicum and R. leguminosarum bv. viciae (Kawaguchi et al. 1990; Sekine et al. 1989); whereas, in B. elkanii, the IPyA-pathway (Fig. 1, number 3) is prominent (Minamisawa et al. 1996). Several genes involved in bacterial IAA synthesis also have been identified. In Azospirillum brasilense, the gene encoding the enzyme indole-3-pyruvate decarboxylase has been isolated (Costacurta et al. 1994). In B. japonicum, the bam gene, a homologue of $t m s-2$ and $i a a H$, was shown to encode indole-3acetamide aminohydrolase that converts IAM to IAA (Sekine et al. 1989).

In this report, we have identified two new genes involved in bacterial IAA synthesis: $\mathrm{y} 4 \mathrm{wE}$ and $\mathrm{y} 4 \mathrm{wF}$, which are under the control of NB15 and the NodD1-SyrM2-NodD2 regulatory cascade. Close homologues of $\mathrm{y} 4 \mathrm{wE}$ and $\mathrm{y} 4 \mathrm{wF}$ have been found in Bradyrhizobium sp. WM9 (ORF 380 and 342) (Stepkowski et al. 2003), Mesorhizobium loti MAFF303099 (mlr5786 and mlr5784) (Kaneko et al. 2000), R7A (msi396 and msi395) (Sullivan et al. 2002), and R. etli CE3 (hisC and yp108) (Hernandez-Gonzalez et al. 2003). In Bradyrhizobium sp. WM9 and both the M. loti strains, homologues of y4wE and $\mathrm{y} 4 \mathrm{wF}$ are arranged in the same order as in NGR234, but without the nod-box. In $R$. etli CE3, the two genes are separated by approximately $80 \mathrm{~kb}$, and a nod-box is upstream of yp108, the $y 4 w F$ homologue. However, none of these homologues is linked to an y4wG-like ORF, supporting our conten-

Table 2. $\beta$-Galactosidase activity of promoter-lacZ fusions in NGR234 carrying nodD2 on the multicopy plasmid pRAF130

\begin{tabular}{lcc}
\hline & \multicolumn{2}{c}{$\beta$-Galactosidase activity (Miller's units) } \\
\cline { 2 - 3 } Promoter, time (hpi) & Noninduced & Daidzein-induced \\
\hline NB8 & $317 \pm 19$ & \\
1 & $302 \pm 22$ & $318 \pm 16$ \\
24 & & $253 \pm 19$ \\
NB15 & $10,300 \pm 800$ & $10,300 \pm 500$ \\
1 & $10,700 \pm 800$ & $11,100 \pm 1,100$ \\
24 & & \\
nodD1p & $12 \pm 0.4$ & $12 \pm 0.6$ \\
1 & $11 \pm 0.2$ & $11 \pm 0.3$ \\
24 & & \\
\hline
\end{tabular}

${ }^{\text {a }} \beta$-Galactosidase assays were used to assess the flavonoid-dependent activities of the nod-boxes NB8 and NB15 as well as the nodD1-promoter (nodD1p) in NGR234 harboring pRAF130. $\beta$-Galactosidase activities are given in Miller's units and were measured 1 and $24 \mathrm{~h}$ postinduction (hpi).

b Values $=$ mean \pm standard error $(n=3)$.
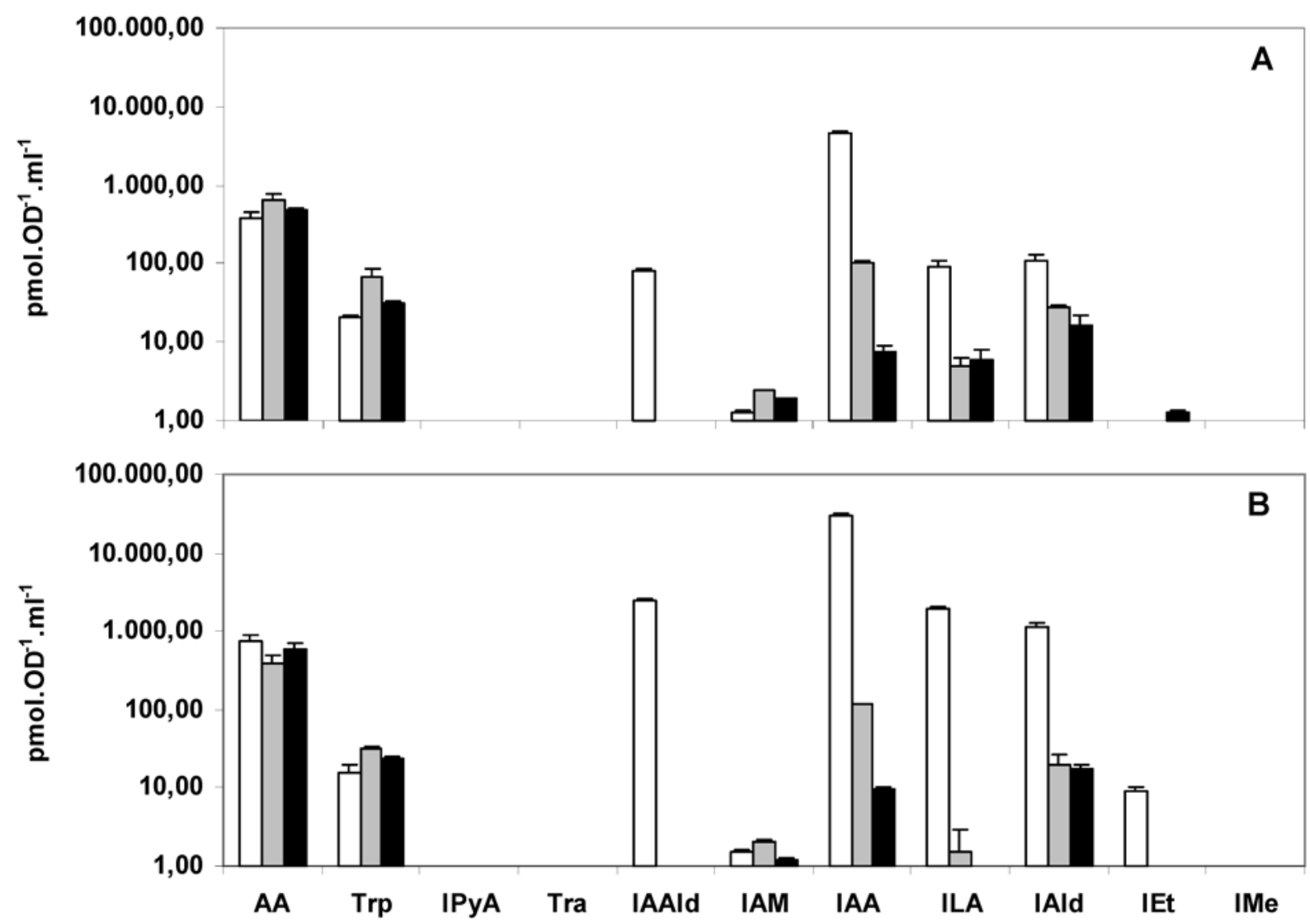

Fig. 6. Intermediates of indole-3-acetic acid (IAA) synthesis found in the supernatants of NGR234 (open bars), and its derivatives NGR $\Omega$ wE (gray bars) and NGR $\Omega w F$ (black bars) grown in Rhizobium minimal medium containing succinate as the carbon source medium for $36 \mathrm{~h}$. A, Bacteria grown without inducer, B, bacteria induced with $0.2 \mu \mathrm{M}$ daidzein. Samples were taken $36 \mathrm{~h}$ after the addition of daidzein and analyzed by liquid chromatography electrospray interface-tandem mass spectrometry. 
tion that $y 4 w G$ is cryptic. Nevertheless, this widespread distribution of $\mathrm{y} 4 \mathrm{wE}$ and $\mathrm{y} 4 \mathrm{wF}$ suggests that they play important roles under natural conditions.

Mutation of either $\mathrm{y} 4 \mathrm{wE}$ or $\mathrm{y} 4 \mathrm{wF}$ abolished flavonoidinduced stimulation of IAA production and diminished constitutive IAA production. Storage and breakdown products of the Tra, IAM, and IPyA pathways were detected, implying that NGR234 is capable of synthesizing IAA by three different pathways. Interestingly, flavonoid induction only stimulated increases in the levels of intermediates of the IPyA pathway, an effect that was absent in the mutants NGR $\Omega w E$ and NGR $\Omega w F$ (Fig. 6). These data strongly suggest that $y 4 w E$ and $\mathrm{y} 4 \mathrm{wF}$ encode enzymes involved in the IPyA pathway (Fig. 1, number 3). Conserved domain searches of public databases suggest that $\mathrm{y} 4 \mathrm{wE}$ encodes a tryptophan transferase and $\mathrm{y} 4 \mathrm{wF}$ an indole-3-acetaldehyde oxidase. Because indole-3acetaldehyde oxidase plays a role in both the IPyA and Tra pathways (Fig. 1, number 2), this observation helps to explain why mutation of $\mathrm{y} 4 \mathrm{wF}$ has more drastic effects on constitutive IAA production than the $\Omega$ insertion into y $4 w E$. Furthermore, although the $\mathrm{y} 4 \mathrm{wE}$ mutant is polar (with attendant effects on downstream ORF including $\mathrm{y} 4 \mathrm{wF}$ ), $\mathrm{y} 4 \mathrm{wF}$ still may be transcribed from the weak constitutive promoter in the intergenic region, thus maintaining activity of the Tra pathway at reduced levels.

It is noteworthy that extra copies of nodD2 converted NB15 into a constitutive promoter, suggesting that NodD2 does not require co-inducers. Similar effects of extra copies of nodD2 on nodC expression were reported in $R$. fredii USDA191 (a close relative of NGR234), while extra copies of nodD1 had no effect (Machado and Krishnan 2003). The response of NB15 to flavonoids is significantly delayed compared with nod-boxes that do not depend on NodD2 (e.g., nod-boxes controlling Nod-factor synthesis) (Kobayashi et al. 2004). Furthermore, mutation of y4wE strongly reduced IAA levels in nodules, indicating that the $\mathrm{y} 4 \mathrm{wEFG}$ operon is

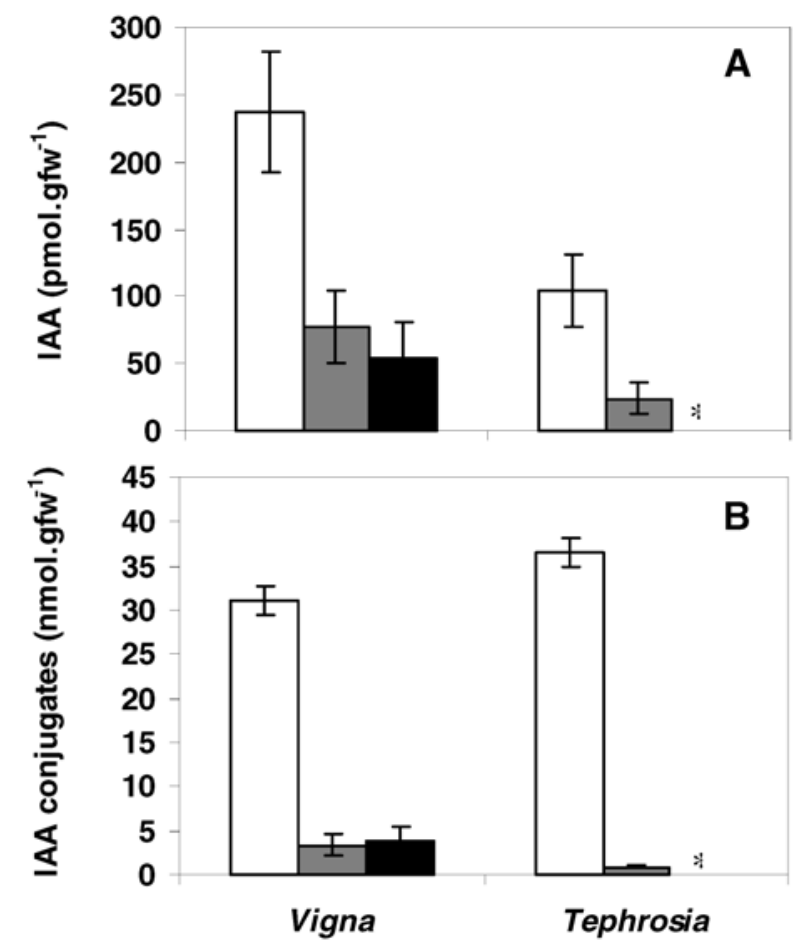

Fig. 7. Concentrations of $\mathbf{A}$, free indole-3-acetic acid (IAA) and $\mathbf{B}$, IAA conjugates in nodules of Vegan unguiculata and Tephrosia vogelii produced by wild-type NGR234 (open bars), the mutant NGR $2 w E$ (gray bars), or the transconjugant NGR $\Omega w E(p w E F G)$ (black bars); * = not tested. transcribed in later stages of the symbiosis. Both lines of evidence suggest that IAA production occurs after Nod-factor synthesis, and that bacterial IAA synthesis plays a role when more intimate contact between bacteria and their hosts has been established. Nod factors inhibit the transport of endogenous IAA, resulting in cortical-cell division, a necessary prelude to the formation of nodule primordia (Mathesius et al. 1998). Kondorosi and associates (1993) observed that IAA-sensitive lines of Medicago varia formed significantly more nodules than less sensitive variants. Our results are less clear cut. Although the y4wEFG locus is expressed in planta and produces significant quantities of IAA, disruption of the locus does not affect nodulation of the two hosts tested. Perhaps flavonoid-inducible IAA synthesis is needed for symbiosis only with certain hosts. Perhaps, too, bacterial IAA synthesis stimulates differentiation of the vascular system enhancing the connections between nodules and roots and, in this way, facilitates the exchange of carbon and nitrogen sources between the symbionts. Alternatively, IAA might act synergistically with other rhizobial signals (e.g., Nod factors, secreted proteins, or polysaccharides). More detailed experiments are planned with a greater number of hosts.

\section{MATERIALS AND METHODS}

Microbiological techniques.

Escherichia coli recombinants were grown at $37^{\circ} \mathrm{C}$ on or in Luria-Bertani media (Sambrook et al. 1989). NGR234 and its derivatives were raised at $27^{\circ} \mathrm{C}$ in or on Rhizobium minimal medium containing succinate as the carbon source (RMS) (Broughton et al. 1986) or TY (Beringer 1974). Ampicillin, gentamycin $(\mathrm{Gm})$, kanamycin $(\mathrm{Km})$, rifampicin (Rif), spectinomycin, and tetracycline were added at concentrations of $100,20,50,50,50$, and $15 \mu \mathrm{g} \mathrm{m} \mathrm{m}^{-1}$, respectively. Tryptophan-supplemented cultures contained L-tryptophan at 1 or $5 \mu \mathrm{g} \mathrm{ml}$. Plasmid constructs were mobilized into NGR234 and its derivatives by triparental matings using pRK2013 as the helper plasmid (Ditta et al. 1980). Flavonoid induction was performed as follows: rhizobial cultures were grown to an optical density at $600 \mathrm{~nm}\left({ }^{1 \mathrm{~cm}} \mathrm{OD}_{600}\right)$ of 0.5 to 0.6 , then diluted to ${ }^{1 \mathrm{~cm}} \mathrm{OD}_{600}=0.1$ in RMS medium and induced with $0.2 \mu \mathrm{M}$ daidzein (Sigma-Aldrich, St. Louis) or $5 \mu \mathrm{M}$ luteolin (Sigma-Aldrich). $\beta$-Galactosidase activity was assayed 1 and $24 \mathrm{~h}$ postinduction (hpi) as described by Miller (Miller 1972). For analysis of IAA and related compounds, 5$\mathrm{ml}$ cultures were harvested $36 \mathrm{hpi}$ when induction of IAA synthesis was maximal. The culture medium (supernatant) and bacterial cells (pellet) were separated by centrifugation (10 s at $3,000 \times g$, room temperature) and stored at $-20^{\circ} \mathrm{C}$ until needed for extraction.

\section{Extraction of IAA and metabolites for analysis by liquid chromatography-tandem mass spectrometry.}

The following were added to $5 \mathrm{ml}$ of the supernatants prepared as described above: $101 \mathrm{ng}$ of ${ }^{13} \mathrm{C}$-IAA (Cambridge Isotope Laboratory, Inc., Andover, MA, U.S.A.), $100 \mathrm{ng}$ of d5-Trp (CON Isotopes Inc., Utrecht, The Netherlands), 150 ng of ${ }^{15} \mathrm{~N}$-anthranilic acid (Cambridge Isotope Labs), and $14.4 \mathrm{ng}$ of ${ }^{13} \mathrm{C}$-IAM (Van Onckelen et al. 1985) as internal tracers and $5 \mathrm{ml}$ of $0.1 \mathrm{M} \mathrm{HCl}$. The supernatant was concentrated on RP-C18 cartridges (Bond-Elut, Varian, Middelburg, The Netherlands). Following rinsing twice with $10 \mathrm{ml}$ of $0.05 \mathrm{M} \mathrm{HCl}$, all indole compounds were eluted from the cartridges with $1.5 \mathrm{ml}$ of acetonitrile (two times). Acetonitrile was evaporated in a Speed Vac (RVC2-25, Christ Freeze Dryers, Osterode, Germany). Before liquid chromatography-tandem mass spectrometry (LC-MS/MS) analysis, the samples 
were dissolved in $100 \mu \mathrm{l}$ of acidified methanol and methylated with ethereal diazomethane following the procedure of Schlenk and Gellerman (1960), dried under nitrogen (TurboVap, LV evaporator; Zymark Corporation, Hopkinton, MA, U.S.A.), and dissolved in $100 \mu \mathrm{l}$ of methanol. After transfer to vials, the samples were dried under nitrogen and redissolved in $20 \%$ methanol.

Bacterial cells were resuspended in $200 \mu \mathrm{l}$ of acidified methanol and sonicated in a Vibracell VCX 400 (with stepped microtip; Sonics \& Materials Inc., Danbury, CT, U.S.A.) for $3 \mathrm{~s}$ at $0^{\circ} \mathrm{C}$ (amplitude of the microtip 40, $400 \mathrm{~W}$, pulse $5 \mathrm{~s}$ followed by a 5 -s cool down period). Afterward, 10 $\mathrm{ml}$ of $0.05 \mathrm{M} \mathrm{HCl}$ was added as well as the internal tracers: $101 \mathrm{ng}$ of ${ }^{13} \mathrm{C}$-IAA, $100 \mathrm{ng}$ of d5-Trp, $150 \mathrm{ng}$ of ${ }^{15} \mathrm{~N}-\mathrm{AA}$, and $14.4 \mathrm{ng}$ of ${ }^{13} \mathrm{C}$-IAM. Cell debris was removed by centrifugation $(10 \mathrm{~s}$ at $3,000 \times g$, room temperature $)$, and the supernatants concentrated on an RP-C18 cartridge, as described above.

Nodules were separated from the roots, frozen in liquid nitrogen, and kept at $-70^{\circ} \mathrm{C}$ until extraction. Still-frozen nodules were crushed with mortar and pestle that was kept cold with liquid nitrogen. Indole compounds were extracted from the plant debris in $80 \%$ methanol at $-20^{\circ} \mathrm{C}$ (overnight). Preparations were divided into two equal aliquots for the analysis of free and conjugated IAA. The free IAA fraction was diluted with distilled water to $50 \%$ ( $\mathrm{vol} / \mathrm{vol}$ ) methanol and purified on a DEAE-Sephadex cartridge (DEAE-Sephadex A25, formate conditions; Pharmacia, Amersham Bioscience, Uppsala, Sweden). After loading and rinsing the DEAE with two additional column volumes of $50 \%$ (vol/vol) methanol, an RP-C18 cartridge was attached beneath the column and eluted with $6 \%$ formic acid. Under these conditions, IAA was concentrated on the RP-C18-cartridge underneath, from which it was eluted with diethyl ether and dried under nitrogen. The IAA conjugates were hydrolyzed for $3 \mathrm{~h}$ in $7 \mathrm{M}$ $\mathrm{NaOH}$ under the flow of water-saturated nitrogen (Bialek and Cohen 1989). After hydrolysis, the samples were desalted on an RP-C18 cartridge at $\mathrm{pH} 2$ and IAA conjugates were extracted as described for free IAA.

\section{Extraction of IAA for measurement by gas chromatography-MS.}

The extraction procedure for supernatants as well as for bacterial pellets prior to gas chromatography (GC)-MS analysis was the same as that described above for measurement by LCMS/MS. ${ }^{13}$ C-IAA (101 ng) was added as an internal tracer and samples were derivatized as described by Epstein and Cohen (1981) using pentafluorobenzylbromide (PFBBr; SigmaAldrich) and ethylpiperidine (Sigma-Aldrich). IAA also was converted into its pentafluorobenzyl (PFB)-ester using this procedure.

\section{LC/(+)ES-MS/MS conditions.}

Samples containing indole compounds were analyzed using a micro-high-performance liquid chromatography (HPLC) system linked to a Quattro II mass spectrometer equipped with an electro-spray interface (LC/(+)ES-MS/MS; Waters, Milford, MA, U.S.A.) Samples $(25 \mu \mathrm{l})$ were injected onto an RP-C18 reversed-phase column (5 $\mu$ l of ODS(3) 100A; 100 by $1.00 \mathrm{~mm}$; Phenomenex, Torrance, CA, U.S.A.) and eluted with a methanol-0.01 $\mathrm{M}$ ammonium acetate gradient (1 min at 20\% MeOH; linear gradient from 20 to $90 \%$ $\mathrm{MeOH}$ in $2 \mathrm{~min} ; 3.5 \mathrm{~min}$ at $90 \% \mathrm{MeOH}, 5 \mathrm{~min}$ at $20 \%$ $\mathrm{MeOH}$, flow $0.06 \mathrm{ml} \mathrm{min}^{-1}$ ) (HPLC pump: BIO-TEK Instruments, system 522; Waters) (Prinsen et al. 1998). Quantification was performed by multiple reactant monitoring of the $\left[\mathrm{MH}^{+}\right]$ion and the appropriate product ion (Prinsen et al.
1997). AA, Trp, IPyA, Tra, IAAld, IAM, ILA, IAld, IEt, IMe, and IAA can be detected with this system. All data were processed by Masslynx software (Waters).

\section{GC-MS conditions.}

Samples extracted for IAA measurement were analyzed by GC-MS. IAA-pentafluorobromide was analyzed by negative chemical ionization GC-MS. The sample $(1 \mu \mathrm{l})$ was injected on a Varian DB-XLB capillary column (15 m, 0.25-mm inside diameter, 0.25- $\mu$ m film thickness) on a Hewlett Packard 5890 series II gas chromatograph with an HP 6890 automatic injector (temperature $325^{\circ} \mathrm{C}$ ), He flow $1.5 \mathrm{ml} \mathrm{min} \mathrm{m}^{-1}$. Temperature gradient was $2 \mathrm{~min}$ at $175^{\circ} \mathrm{C}$, from 175 to $300^{\circ} \mathrm{C}$ at $15^{\circ} \mathrm{C} \mathrm{m^{-1 }}$, and $300^{\circ} \mathrm{C}$ for $2 \mathrm{~min}$. Quantification was performed on a VG Trio 2000 mass spectrometer in the negative chemical ionization mode (Waters, Micromass) using methane as the ionization gas. Detection was performed in the ion-monitoring mode, using $\mathrm{m} / \mathrm{z} 180$ and 174 for the quantification of ${ }^{13} \mathrm{C}$-IAA-PFB and IAA-PFB, respectively. Data were processed by Masslynx software (Waters).

\section{Construction of $\mathrm{y} 4 \mathrm{wE}$ and $\mathrm{y} 4 \mathrm{wF}$ mutants and plasmids.}

To mutate y4wE, cosmid pXB368 (Perret et al. 1991) was digested with $B g l \mathrm{II}$, and the $3.4-\mathrm{kb}$ fragment containing $\mathrm{y} 4 \mathrm{wE}$ was purified and cloned into the BamHI site of pJQ200-mp18 (Quandt and Hynes 1993). A BamHI fragment from pHP $45 \Omega$ (Fellay et al. 1987) containing the spectinomycin-resistant $\Omega$ interposon was inserted into the unique XhoI site within $\mathrm{y} 4 \mathrm{wE}$ after treatment with the Klenow fragment. To mutate $\mathrm{y} 4 \mathrm{wF}$, cosmid pXB368 was digested with BamHI, and the 5.8-kb fragment containing NB15 as well as $\mathrm{y} 4 \mathrm{wEFG}$ was purified and cloned into the BamHI site of pJQ200-mp18 (this same BamHI fragment also was cloned into the BamHI site of pLAFR-6, giving rise to pwEFG). A BamHI fragment from pHP $45 \Omega-\mathrm{Km}$ containing the kanamycin-resistant $\Omega$ interposon was inserted into the unique $B g l$ II site within $\mathrm{y} 4 \mathrm{wF}$. The BamHI fragment containing the interposon-inserted $\mathrm{y} 4 \mathrm{wF}$ was cloned into the BamHI site of pLAFR-6 giving pwE(F $\Omega) G$. The upstream region of $y 4 w F$ was amplified by PCR from pwEFG using wFpF (5'GCGTCTAGATAACCGCTATTCG- $\left.3^{\prime}\right)$ and wFpR (5'TGCCAATGCATTACCGTCCTCG-3') as primers and $p f u$ DNA polymerase (Stratagene, La Jolla, CA, U.S.A.). This 952-bp fragment then was cloned into the EcoRV site of pBluescriptKS+ (Stratagene) and later as an $\mathrm{XbaI}-N_{\text {siI }}$ insert into the XbaI-Pst I sites of pMP220 (resulting in plasmid pMP-wF5'). Plasmids were mobilized into NGR234 by triparental matings. For constructs to knock out $\mathrm{y} 4 \mathrm{wF}$ and $\mathrm{y} 4 \mathrm{wE}$, transconjugants first were selected on TY plates containing Rif and Gm, then on TY plates containing Rif, Km, and $5 \%(\mathrm{wt} / \mathrm{vol})$ sucrose to select for double crossovers. Marker exchange leading to NGR $\Omega w E$ and NGR $\Omega w F$ was confirmed by Southern hybridizations.

\section{Plant assays.}

Nodulation tests were performed in Magenta jars (Magenta Corp., Chicago) (Lewin et al. 1990). All plants were grown at a day temperature of $26^{\circ} \mathrm{C}$, a night temperature of $20^{\circ} \mathrm{C}$, and a photoperiod of $16 \mathrm{~h}$. Each plant was inoculated with $10^{8}$ bacteria and harvested 6 to 8 weeks after inoculation.

\section{ACKNOWLEDGMENTS}

We thank H. Van Onckelen for his constant encouragement and support as well as Y.-Y. Aung, D. Gerber, S. Öden, and S. Foubert for their skilful technical assistance. H. Kobayashi acknowledges the kind support of Y. Murooka of the University of Osaka. This work was financed by the Fund for Scientific Research-Flanders (Belgium) (F.W.O. G.0276.01 to E. 
Prinsen and F.W.O. W.O.G. on plant-microbe interaction to E. Prinsen and W. Broughton). W. J. Broughton thanks the Fonds National de la Recherche Scientifique (Project 31-63893.00) and the Université de Genève for financial support.

\section{LITERATURE CITED}

Badenoch-Jones, J., Summons, R. E., Entsch, B., Rolfe, B. G., Parker, C. W., and Letham, D. S. 1982. Mass spectrometric identification of indole compounds produced by Rhizobium strains. Biomed. Mass Spectrom. 9:429-437.

Basu, P. S., and Ghosh, A. C. 1998. Indole acetic acid and its metabolism in root nodules of a monocotyledonous tree Roystonea regia. Curr Microbiol. 37:137-140.

Basu, P. S., and Ghosh, A. C. 2001. Production of indole acetic acid in culture by a Rhizobium species from the root nodules of a monocotyledonous tree, Roystonea regia. Acta Biotechnol. 21:65-72.

Beringer, J. E. 1974. R factor transfer in Rhizobium leguminosarum. J. Gen. Microbiol. 84:188-198.

Bialek, K., and Cohen, J. D. 1989. Quantitation of indole acetic acid conjugates in bean seeds by direct tissue hydrolysis. Plant Physiol. 90:398400

Broughton, W. J., Wong, C.-H., Lewin, A., Samrey, U., Myint, H., Meyer, A. H., Dowling, D. N., and Simon, R. 1986. Identification of Rhizobium plasmid sequences involved in recognition of Psophocarpus, Vig$n a$, and other legumes. J. Cell Biol. 102:1173-1182.

Costacurta, A., Keijers, V., and Vanderleyden, J. 1994. Molecular cloning and sequence analysis of an Azospirillum brasilense indole-3-pyruvate decarboxylase gene. Mol. Gen. Genet. 243:463-472.

Costacurta, A., and Vanderleyden, J. 1995. Synthesis of phytohormones by plant-associated bacteria. Crit. Rev. Microbiol. 21:1-18.

Datta, C., and Basu, P. S. 1998. Production of indole acetic acid in root nodules and culture by a Rhizobium species from root nodules of the fodder legume Melilotus alba DESR. Acta Biotechnol. 18:53-62.

Datta, C., and Basu, P. S. 2000. Indole acetic acid production by a Rhizobium species from root nodules of a leguminous shrub, Cajanus cajan. Microbiol. Res. 155:123-127.

Ditta, G., Stanfield, S., Corbin, D., and Helsinki, D. R. 1980. Broad host range DNA cloning system for Gram-negative bacteria. Construction of a gene bank of Rhizobium meliloti. Proc. Natl. Acad. Sci. U.S.A. 77:7347-7351.

Downie, J. A. 1998 Functions of rhizobial nodulation genes. Pages 387402 in: The Rhizobiaceae. H. P. Spaink, A. Kondorosi, and P. J. J. Hooykaas, eds. Kluwer Academic Press, Dordrecht, The Netherlands.

Epstein, E., and Cohen, J. D. 1981. Microscale preparation of pentafluorobenzyl esters: Electron-capture gas chromatographic detection of indole-3-acetic acid from plants. J. Chromatogr. 209:413-420.

Ernstsen, A., Sandberg, G., Crozier, A., and Wheeler, C. T. 1987. Endogenous indoles and the biosynthesis and metabolism of indole-3-acetic acid in cultures of Rhizobium phaseoli. Planta 171:422-428.

Fellay, R., Frey, J., and Krisch, H. 1987. Interposon mutagenesis of soil and water bacteria: a family of DNA fragments designed for in vitro insertional mutagenesis of gram-negative bacteria. Gene 52:147-154.

Fellay, R., Hanin, M., Montorzi, G., Frey, J., Freiberg, C., Golinowski, W., Staehelin, C., Broughton, W. J., and Jabbouri, S. 1998. nodD2 of Rhizobium sp. NGR234 is involved in the repression of the nodABC operon. Mol. Microbiol. 27:1039-1050.

Fellay, R., Perret, X., Viprey, V., Broughton, W. J., and Brenner, S. 1995. Organization of host-inducible transcripts on the symbiotic plasmid of Rhizobium sp. NGR234. Mol. Microbiol. 16:657-667.

Feng, J., Li, Q., Hu, H. L., Chen, X. C., and Hong, G. F. 2003. Inactivation of the nod box distal half-site allows tetrameric NodD to activate nodA transcription in an inducer-independent manner. Nucleic Acids Res. 31:3143-3156.

Fisher, R. F., and Long, S. R. 1993. Interactions of NodD at the nod box: NodD binds to two distinct sites on the same face of the helix and induces a bend in the DNA. J. Mol. Biol. 233:336-348.

Freiberg, C., Fellay, R., Bairoch, A., Broughton, W. J., Rosenthal, A., and Perret, X. 1997. Molecular basis of symbiosis between Rhizobium and legumes. Nature 387:394-401.

Fukuhara, H., Minakawa, Y., Akao, S., and Minamisawa, K. 1994. The involvement of indole-3-acetic acid produced by Bradyrhizobium elkanii in nodule formation. Plant Cell Physiol. 35:1261-1265.

Hernandez-Gonzalez, I., Hernandez-Celis, J. C., Quintero, V., MorenoHagelsieb, G., Girard, L., Rodriguez, O., Flores, M., Cevallos, M. A., Collado-Vides, J., Romero, D., and Davila, G. 2003. The mosaic structure of the symbiotic plasmid of Rhizobium etli CFN42 and its relation to other symbiotic genome compartments. Genome Biol. 4:R36.

Jameson, P. 2000. Cytokinins and auxins in plant-pathogen interactions-
An overview. Plant Growth Regul. 32:369-380.

Kaneko, T., Nakamura, Y., Sato, S., Asamizu, E., Kato, T., Sasamoto, S., Watanabe, A., Idesawa, K., Ishikawa, A., Kawashima, K., Kimura, T., Kishida, Y., Kiyokawa, C., Kohara, M., Matsumoto, M., Matsuno, A. Mochizuki, Y., Nakayama, S., Nakazaki, N., Shimpo, S., Sugimoto, M., Takeuchi, C., Yamada, M., and Tabata, S. 2000. Complete genome structure of the nitrogen-fixing symbiotic bacterium Mesorhizobium loti. DNA Res. 7:331-338.

Kawaguchi, M., Sekine, M., and Syono, K. 1990. Isolation of Rhizobium leguminosarum biovar viciae variants with indole-3-acetamide hydrolase activity. Plant Cell Physiol. 31:449-455.

Kobayashi, H., Naciri-Graven, Y., Broughton, W. J., and Perret, X. 2004. Flavonoids induce temporal shifts in gene expression of nod-box controlled loci in Rhizobium sp. NGR234. Mol. Microbiol. 51:335-347.

Kondorosi, E., Schultze, M., Savouré, A., Hoffmann, B., Dudits, D., Pierre, M., Allison, L., Bauer, P., Kiss, G. B., and Kondorosi, A. 1993. Control of nodule induction and plant cell growth by Nod factors. Pages 143-150 in: Advances in Molecular-Genetics of Plant-Microbe Interactions. E. W. Nester and D. P. S. Vema, eds. Kluwer Academic Publishers, Dordrecht, The Netherlands.

Kovach, M. E., Elzer, P. H., Hill, D. S., Robertson, G. T., Farris, M. A., Roop, R. M., and Peterson, K. M. 1995. Four new derivatives of the broad-host-range cloning vector pBBR1MCS, carrying different antibiotic-resistance cassettes. Gene 166:175-176.

Lewin, A., Cervantes, E., Wong, C.-H., and Broughton, W. J. 1990. nodSU, two new nod genes of the broad host range Rhizobium strain NGR234 encode host-specific nodulation of the tropical tree Leucaena Leucocephala. Mol. Plant-Microbe Interact. 27:317-326.

Machado, D., and Krishnan, H. B. 2003. nodD alleles of Sinorhizobium fredii USDA191 differentially influence soybean nodulation, nodC expression, and production of exopolysaccharides. Curr. Microbiol. 47:134-137.

Mathesius, U., Schlaman, H. R. M., Spaink, H. P., Sautter, C., Rolfe, B. G., and Djordjevic, M. A. 1998. Auxin transport inhibition precedes root nodule formation in white clover roots and is regulated by flavonoids and derivatives of chitin oligosaccharides. Plant J. 14:23-34.

Miller, J. F. 1972. Experiments in Molecular Genetics. Cold Spring Harbor Laboratory Press, Cold Spring Harbor, NY.

Minamisawa, K., and Fukai, K. 1991. Production of indole-3-acetic acid by Bradyrhizobium japonicum: a correlation with genotype grouping and rhizobitoxine production. Plant Cell Physiol. 32:1-9.

Minamisawa, K., Ogawa, K., Fukuhara, H., and Koga, J. 1996. Indole pyruvate pathway for indole-3-acetic acid biosynthesis in Bradyrhizobium elkanii. Plant Cell Physiol. 37:449-453.

Morris, R. O. 1995. Genes specifying auxin and cytokinin biosynthesis in prokaryotes. Pages 318-339 in: Plant Hormones Physiology, Biochemistry and Molecular Biology, 2nd ed. P. J. Davies, ed. Kluwer Academic Publishers, Dordrecht, The Netherlands.

Patten, C. L., and Glick, B. R. 1996. Bacterial biosynthesis of indole-3acetic acid. Can. J. Microbiol. 42:207-220.

Perret, X., Broughton, W. J., and Brenner, S. 1991. Canonical ordered cosmid library of the symbiotic plasmid of Rhizobium species NGR234. Proc. Natl. Acad. Sci. U.S.A. 88:1923-1927.

Perret, X., Freiberg, C., Rosenthal, A., Broughton, W. J., and Fellay, R. 1999. High-resolution transcriptional analysis of the symbiotic plasmid of Rhizobium sp. NGR234. Mol. Microbiol. 32:415-425.

Perret, X., Staehelin, C., and Broughton, W. J. 2000. Molecular basis of symbiotic promiscuity. Microbiol. Mol. Biol. Rev. 64:180-201.

Prinsen, E., Chauvaux, N., Schmidt, J., John, M., Wieneke, U., Degreef, J., Schell, J., and Van Onckelen, H. 1991. Stimulation of indole-3-acetic acid production in Rhizobium by flavonoids. FEBS (Fed. Eur. Biol. Soc.) Lett. 282:53-55.

Prinsen, E., Van Dongen, W., Esmans, E. L., and Van Onckelen, H. 1997. HPLC linked electrospray tandem mass spectrometry: a rapid and reliable method to analyse indole-3-acetic acid metabolism in bacteria. $\mathrm{J}$. Mass Spectrom. 32:12-22.

Prinsen, E., Van Dongen, W., Esmans, E. L., and Van Onckelen, H. A. 1998. Micro and capillary liquid chromatography-tandem mass spectrometry: a new dimension in phytohormone research. J. Chromatogr. A 826:25-37.

Pueppke, S. G., and Broughton, W. J. 1999. Rhizobium sp. strain NGR234 and $R$. fredii USDA257 share exceptionally broad, nested host ranges. Mol. Plant-Microbe Interact. 12:293-318.

Quandt, J., and Hynes, M. F. 1993. Versatile suicide vectors which allow direct selection for gene replacement in gram-negative bacteria. Gene 127:15-21.

Relić, B., Talmont, F., Kopcinska, J., Golinowski, W., Prome, J.-C., and Broughton, W. J. 1993. Biological activity of Rhizobium sp NGR234 Nod-Factors on Macroptilium-atropurpureum. Mol. Plant-Microbe Interact. 6:764-774. 
Sambrook, J., Fritsch, E. F., and Maniatis, T. 1989. Molecular Cloning: A Laboratory Manual. Cold Spring Harbor Laboratory Press, Cold Spring Harbor, NY, U.S.A.

Schlenk, H., and Gellerman, J. L. 1960. Esterification of fatty acids with diazomethane on a small scale. Anal. Chem. 32:1412-1414.

Sekine, M., Watanabe, K., and Syõno, K. 1989. Molecular cloning of a gene for indole-3-acetamide hydrolase from Bradyrhizobium japonicum. J. Bacteriol. 171:1718-1724.

Spaink, H. P., Okker, R. J. H., Wijffelman, C. A., Pees, E., and Lugtenberg, B. J. J. 1987. Promoters in the nodulation region of the Rhizobium leguminosarum Sym plasmid pRL1JI. Plant Mol. Biol. 9:27-39.

Stepkowski, T., Swiderska, A., Miedzinska, K., Czaplinska, M., Swiderski, M., Biesiadka, J., and Legocki, A. B. 2003. Low sequence similarity and gene content of symbiotic clusters of Bradyrhizobium sp. WM9 (Lupinus) indicate early divergence of "lupin" lineage in the genus Bradyrhizobium. Antonie Leeuwenhoek. 84:115-24

Sullivan, J. T., Trzebiatowski, J. R., Cruickshank, R. W., Gouzy, J., Brown, S. D., Elliot, R. M., Fleetwood, D. J., McCallum, N. G., Rossbach, U., Stuart, G. S., Weaver, J. E., Webby, R. J., De Bruijn, F. J., and Ronson, C. W. 2002. Comparative sequence analysis of the symbiosis island of Mesorhizobium loti strain R7A. J. Bacteriol. 184:3086-3095.

Van Onckelen, H., Rudelsheim, P. L., Inze, D., Follin, A., Messens, E., Horemans, S., Schell, J., Van Montagu, M., and Degreef, J. A. 1985 Tobacco plants transformed with the Agrobacterium T-DNA gene- 1 contain high amounts of indole-3-acetamide. FEBS (Fed. Eur. Biol. Soc.) Lett. 181:373-376. 